Bangladesh J. Bot. 43(2): 123-129, 2014 (September)

\title{
COMPARATIVE MORPHOLOGICAL, ANATOMICAL AND PALYNOLOGICAL STUDIES ON TRIGONELLA (FABACEAE) IN KHORASSAN RAZAVI PROVINCE (NE IRAN)
}

\author{
SAmaneh Ghadiri, Azarnoosh Jafari* and Mohammad Mahdi Hamdi ${ }^{1}$ \\ Department of Biology, Mashhad Branch, Islamic Azad University, Mashhad, Iran
}

Key words: Anatomical characters, Pollen ornamentation, Trigonella

\begin{abstract}
Morphological, anatomical and palynological characters of five species of Trigonella growing in Khorassan Razavi province were examined. In morphological study, the differences of vegetative and floral features were assessed. Then cluster analysis was done using UPGMA to recognize the affinity between species. Moreover PCA analysis was carried out to identify species diversity and valuable features for species identification. For anatomical research, the cross sections of the stems and leaflets were prepared and stained by differential staining. In palynological study, the pollen were extracted, acetolysed and observed by SEM. The results of cluster analysis showed circumscription between species and sections. Moreover PCA analysis indicated species diversity and useful traits for identification. The anatomical results displayed some variations in vessel arrangement and cell type of xylary fiber in stem between species. Furthermore, pollen ornamentation was variable among species and helped to identify them.
\end{abstract}

\section{Introduction}

The genus Trigonella L. belongs to Fabaceae Lindl. which distributed in west Asia, Europe, north and south Africa, north America, Australia and China (Mabberly 1977, Rechinger 1984, Federov 1987, Davis 1989, Chase and Reveal 2009). This genus comprises around 32 species in Iran which six species growing in NE Iran (Khorassan Razavi province) that belong to the sections Buceratos Boiss., Falatulae Boiss., Verae Sirj. and Reflexae Sirj. (Rechinger 1984, Mousavi and Khosravi 2010).

Besides morphological characters, anatomical and palynological features were evaluated to identify variations among species. In previous study, anatomical characters have been compared between two species of Trigonella (Ranjbar et al. 2012). The previous palynological studies were done on the pollen of Trifolieae tribe and some species of Trigonella (Gazar 2003, Taia 2004, Lashin 2006). Due to deficiency of information of anatomical and palynological features of Iranian Trigonella, biosystematical studies were done on five species distributed in NE Iran for recognition of different characters among species and their role in identification of species and sections circumscription.

\section{Materials and Methods}

Five taxa of Trigonella including $T$. orthoceras Kar. and T. monantha subsp. monantha Meyer from sect. Bucerates, T. foenum- graecum L. from sect. Falatula, T. grandiflora Bunge. from sect. verae and T. monspeliaca L. from sect. Reflexae were examined. Most samples of Trigonella were prepared either from fresh materials collected in the field of Khorassan Razavi province during May - July, 2011 (Table 1) or from dry specimens kept in FUMH. Voucher specimens were deposited in Islamic Azad University, Mashhad branch herbarium (IAUM). The

*Author for correspondence: <azarnoosh.jafaree@hotmail.com>. ${ }^{1}$ Department of Biology, Garmsar Branch, Islamic Azad University, Garmsar, Iran. 
morphological characters, like life form, presence trichomes on stems, the shape of stipules, leaflet, legume, floral segments and length of calyx and corolla were assessed among species. Cluster analysis was done based on vegetative and floral features by NTSYS software ver. 20.02 using UPGMA method. Also, for identification of valuable morphological characters used for taxonomy, PCA analysis was carried out by CANOCO software ver. 4 .

Table 1. The locality of studied Trigonella species.

\begin{tabular}{|c|c|}
\hline Species & Locality \\
\hline $\begin{array}{l}\text { T. monantha subsp. } \\
\text { monantha }\end{array}$ & $\begin{array}{l}\text { Taibad to Dogharou, } 700 \text { m, 18247, FUMH; Mashhad, Pardis, } 1040 \text { m, } 37710 \text {, } \\
\text { FUMH; Between Mazdavand- Sarakhs, } 650 \text { m, 35003, FUMH; Kalate Naderi to } \\
\text { Darchangan, } 1100 \text { m, 28937, FUMH; Between Mashhad- Moghan, north of } \\
\text { Sarborj, } 1450 \text { m, 21986, FUMH; Chenaran, between Abghad- Ferizi, } 1300 \text { m, } \\
\text { 9051, IAUM; Gonabad, Sar Asiab, } 1800 \text { m, 9052, IAUM. }\end{array}$ \\
\hline T. orthoceras & $\begin{array}{l}\text { Mashhad, Kang mountains, } 2100 \text { m, 20990, FUMH; North of Quchan, Aslameh, } \\
2000 \text { and } 2300 \text { m, } 9055 \text { and 34742, IAUM and FUMH. }\end{array}$ \\
\hline T. foenum-graecum & Mashhad, Kardeh village, 1100m, IAUM. \\
\hline T. monspeliaca & $\begin{array}{l}\text { South of Dargaz, Ghazah Ghoz mountains, } 1450 \text { m, 16437, FUMH; Dargaz, } \\
\text { Tandoureh, between Shekarabad- Chehel mir, } 2300 \text { m, 20490, FUNH; Mashhad, } \\
\text { Kalat, } 13450 \text { m, 9045, IAUM. }\end{array}$ \\
\hline T. grandiflora & $\begin{array}{l}\text { South of Saraks, Khatoun bridge, } 900 \text { m, 31862, FUMH; } 9 \text { km Sarakhs-Mashhad, } \\
284 \text { m, 13987, FUMH; Chenaran, Ardakan village, } 1500 \text { m, 9053, IAUM }\end{array}$ \\
\hline
\end{tabular}

For anatomical study, cross sections were made from the base of stems and middle part of leaflets. They were stained by green methyl and carmine, then photographed by different magnification of light microscopy (LM) ZEISS model 1.25X, CONTAX camera model 167MT. Anatomical characters such as shape of vascular bundles, arrangement of vessels, number of epidermis and cortex layer in stem and mesophyll type in leaflet, were analyzed.

For the palynological study, the pollen grains of three species were extracted from the anther, acetolised and studied by SEM at magnification 5000 and 20000 (Erdtman 1966, Moore et al. 1991). The characters such as $P$ (polar axis length), $E$ (equatorial axis length), $P / E$ ratio and pollen ornamentation were assessed. The electro-micrographs were obtained with a Leo-1455 vp scanning electron microscope. The pollen terminology in general followed Punt et al. (2007).

\section{Results and Discussion}

The morphological study showed significant variations between species in terms of vexilum, wing and keel shape and apex, the shape of stipule, legume and legume nerves, life form and calyx length/corolla length. The shape of vexilum were observed cordate - obovate in T. orthoceras and T. foeunm-graecum though obovate in the others. Vexilum apex in T. monantha subsp. monantha, T. grandiflora and T. monspeliaca was obtuse while in $T$. foenum-graecum and $T$. orthoceras was emarginate. Wing apex was acute in T. orthoceras, T. grandiflora and T. monantha subsp. monantha, obtuse in $T$. foenum-graecum and retuse in T. monspeliaca. Legum nerves in $T$. monantha subsp. monantha, T. foenum-graecum and $T$. orthoceras were parallel while in $T$. monspeliaca and T. grandiflora were reticulate and oblique, respectively. Stipules shape was very different for example in T. monantha subsp. monantha, T. orthoceras and T. monspeliaca were almost sagittate. Also in $T$. foenum-graecum and $T$. grandiflora were hairy triangular- lanceolate and hairy lanceolate, respectively (Table 2). Cluster analysis of morphological characters showed species distinct circumscription. T. foenum-graecum posed far from the others. T. grandiflora was 
separated from T. monantha subsp. monantha, $T$. monspeliaca and $T$. orthoceras due to difference of leaf width, corolla color, calyx hairs and the shape of leaflet margin. T. monspeliaca differed from $T$. monantha subsp. monantha and T. orthoceras because difference of legume nerves, stipule shape. Moreover, T. monantha subsp. monantha was separated from T. orthoceras due

Table 2. Morphological features of studied Trigonella species.

\begin{tabular}{|c|c|c|c|c|c|}
\hline Species & $\begin{array}{l}\text { Vexilum } \\
\text { shape }\end{array}$ & $\begin{array}{l}\text { Wing } \\
\text { apex }\end{array}$ & $\begin{array}{l}\text { Legume } \\
\text { nerves }\end{array}$ & $\begin{array}{l}\text { Stipule } \\
\text { shape }\end{array}$ & $\begin{array}{l}\text { Calyx length/ } \\
\text { corolla length }\end{array}$ \\
\hline $\begin{array}{l}\text { T. monantha } \\
\text { subsp. monantha }\end{array}$ & Obovate-obtuse & Acute & Parallel & Sagittate-dentate & 1 \\
\hline T. orthoceras & $\begin{array}{l}\text { Cordate-obovate, } \\
\text { Emarginated }\end{array}$ & Acute & Parallel & Sagittate & $<1$ \\
\hline T. foenum-graecum & $\begin{array}{l}\text { Cordate-obovate, } \\
\text { Emarginated }\end{array}$ & Obtuse & Parallel & $\begin{array}{l}\text { Hairy triangular } \\
\text {-lanceolate }\end{array}$ & $1>$ \\
\hline T. monspeliaca & obovate-obtuse & Retuse & Reticulate & Sub sagittate & $1<$ \\
\hline T. grandiflora & obovate-obtuse & Acute & Oblique & Hairy lanceolate & $1>$ \\
\hline
\end{tabular}

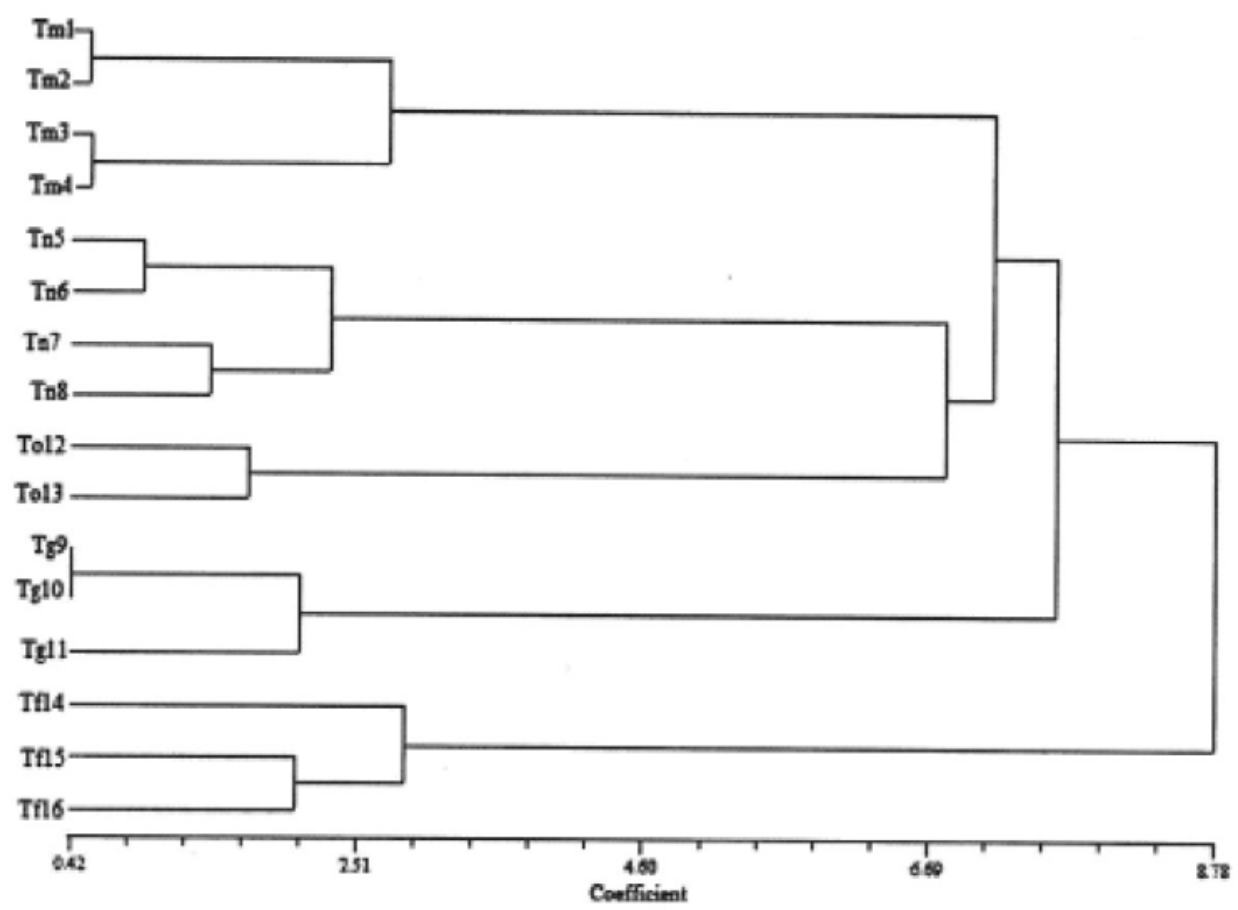

Fig. 1 A. Drawn dendrogram of cluster analysis based on morphological characters.

Tm1: T. monspeliaca (1, 2: Mashhad, Kalat, 3, 4: Mashhad, Zosk.). Tn: T. monantha subsp. monantha (5: Chenaran between Abghad and Ferizi, 6, 7, 8: Gonabad, Sarasiab). Tg: T. grandiflora (9, 10, 11: Chenaran, Radkan). To: T. orthoceras (12: Mashhad, Kang; 13: North of Quchan, Aslameh). Tf: T. foenum- graecum (14, 15, 16: North of Torbat Heidarieh, Khomari pass). 
to difference in seed size, life form, the shape of corolla segments and leaflet and calyx hairs. PCA analysis indicated valuable features to identify species like life form, legum and stipule shape, calyx length/corolla length, stem and legume hairs. Moreover, distribution of specie showed no overlapping (Figs 1A-B).

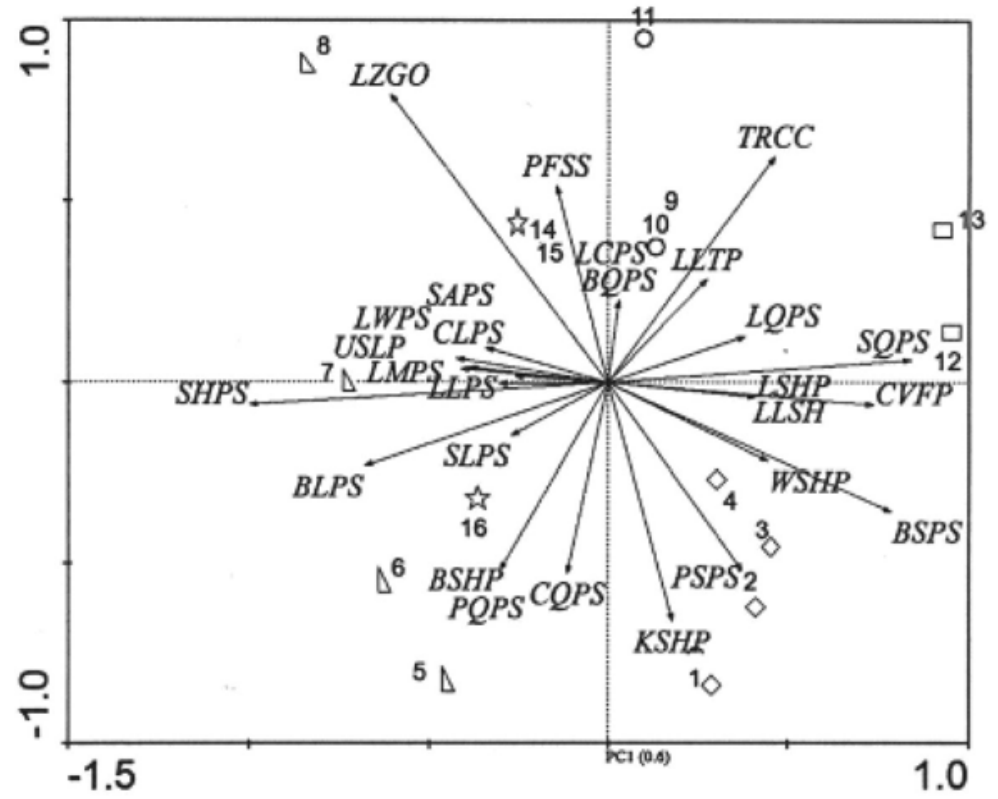

T. monspeliaca: $\diamond, T$. monantha subsp. monantha: $\triangle, T$. grandiflora: $\bigcirc$

\section{T. orthoceras: $\square$, T. foemum-graecum: मे}

Fig. 1 B. Diagram of PCA analysis showing important traits for identification and species diversity.

LZGO: Legume shape, PFSS: Habit, TRCC: tooth length/ tube length in corolla, LLTP: Leaflet apex, LCPS: Legume curving, BQPS: Bracts trichoms, BLPS: bracts length, SQPS: Stem trichomes, CLPS: Calyx length, USLP: Trichoms on the abaxial side of leaflet, LLPS: leaf length, LWPS: leaf width, LMPS: Leaflet margin. SHPS: Stem length, SAPS: Seed width, SLPS: Seed length, PQPS: Stipule trichomes, PSPS: Stipule shape, LLSH: Leaflet shape, WSHP: Wing apex, KSHP: Keel shape, BSHP: Vexilum shape, CQPS: Calyx trichom, BSPS: Bract shape, CVFP: Legum coat nerves, LSHP: Legum length, LQPS: Legum trichom.

Anatomical results of stem, revealed discontinuous sclerid above the phloem, radial chain pore- solitary vessel arrangement in $T$. orthoceras, radial chain pore in $T$. monantha subsp. monantha, T. foenum-graecum and T. monspeliaca, and radial chain pore- cluster in $T$. grandiflora. Just gelatinous fiber was observed in xylary fiber of $T$. monantha subsp. monantha. Moreover, the cortex thickness in T. monantha subsp. monantha was less than the others. Xylem bundles were compact- wide and lax- narrow in T. monantha subsp. monthana and T. foenumgraecum respectively (Figs 2A-E). In leaflets cross section of studied species, mesophyll was observed dorsi-ventral (Fig. 2F). According to anatomical results, just vessel arrangement was variable among species. Presence of gelatinous fiber in T. monantha subsp. monantha stem confirmed this species was adapted to dry habitate. On the other hand Ranjbar et al reported, the difference were observed between stem cross sections of T. elliptica and T. yasujensis. The outline of stem transverse section and type of parenchyma tissue in peduncle were pentagonal and spongy in T. yasujensis while in T. elliptica were sinuate and palisade- spongy respectively (Ranjbar et al. 2012). 
Palynological results displayed pollen in $T$. foenum-graecum and $T$. monantha subsp. monantha were prolate- sub prolate and oblong spherical in T. orthoceras. High variation was observed in pollen ornamentation i.e. echinate- porate in $T$. orthoceras, porate in $T$. monantha subsp. monantha, reticulate in T. foenum-garecum. Also, Taia has reported oblong- spherical and granulate pollen in T. monspeliaca (Taia 2004). Moreover, T. foenum- graecum and T. orthoceras had the maximum and minimum pollen size (Figs 3A- F, Table 3). Indeed, pollen ornamentation
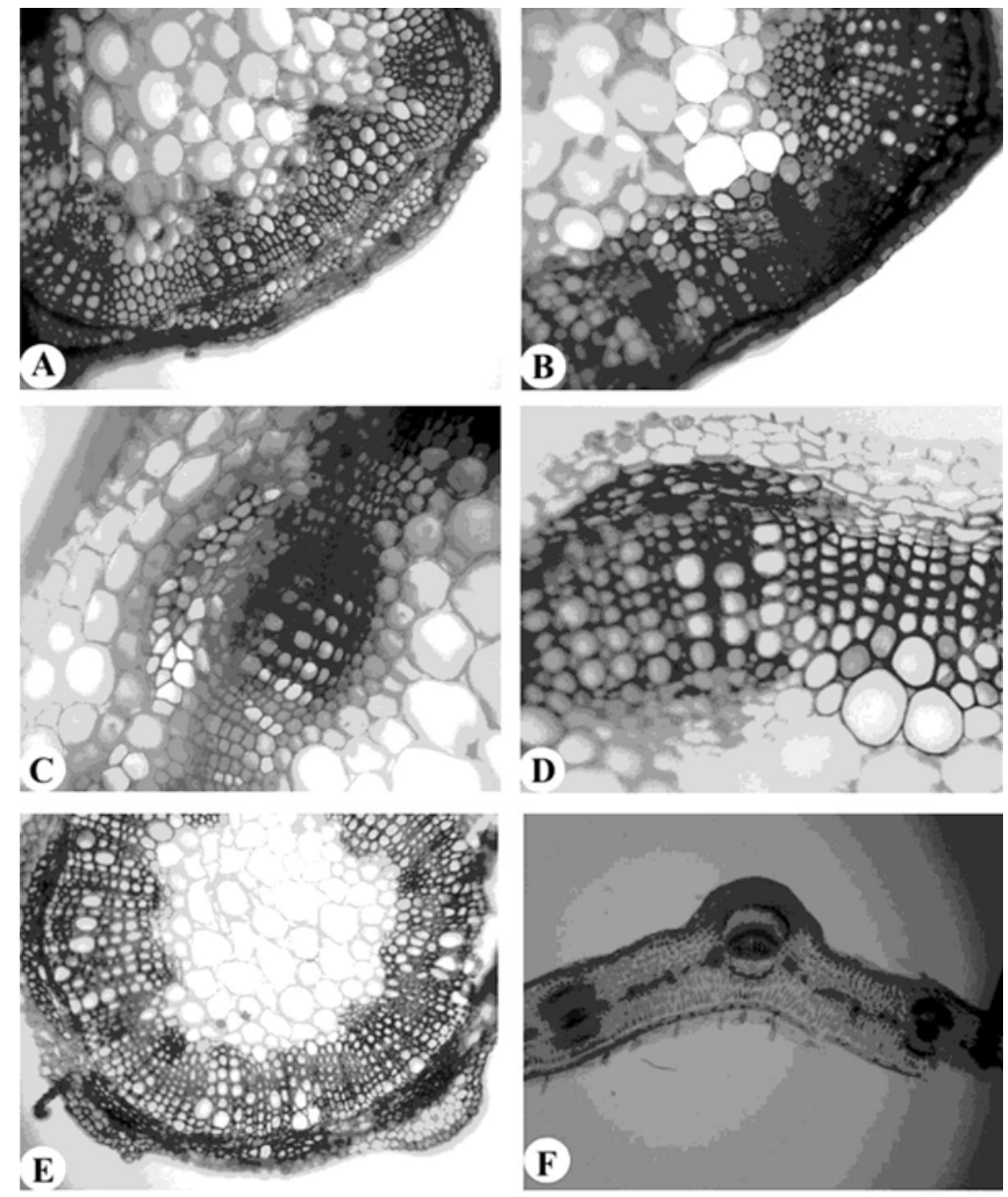

Fig. 2. Cross section of stems. (A) radial chain pore-solitary vessel arrangement in T. orthoceras (B-D) radial chain pore in $T$. monantha subsp. monantha, $T$. foenum-graecum and T. monspeliaca. (E) radial chain pore- cluster in T. grandiflora. The arrow showing gelatinous fiber. (F) Dorsi-ventral mesophyll in leaflet cross section of $T$. orthoceras.

was useful character to identify species. According to Taia's report, T. arabica Del., T. anguina Del, T. anguina Del., T. stellata Forssk. had aperture with soft margin while T. hamosa L., T. maritime Del., T. laciniata L., T. monspeliaca L. had granulate margin. Pollen ornamentation was reticulate in T. arabica, T. occulata Del. ex DC., T. stellata, T. laciniata, T. maritime, granulate in T. hamosa, T. mospeliaca and granulate- porate in T. anguina (Taia 2004). Based on Lashin's report, pollen of $T$. foenum graecum was prolate, tricolporate and reticulate which these characters 
were similar to the present research results except pollen shape in polar view. In the present study the shape of pollen reported prolate or sub-prolate pollen. He pointed $T$. stellata had sub prolate, reticulate pollen too (Lashin 2006).

Table 3. The details of studied Trigonella pollen.

\begin{tabular}{llll}
\hline Species & P/E & $\begin{array}{l}\text { Meso-colpium } \\
\text { length }\end{array}$ & Ornamentation \\
\hline T. monantha subsp. monntha & 1.17 & 24 & Porate \\
T. orthoceras & 1.03 & 32 & Echinate-porate \\
T. foeunum-graecum & 1.35 & 36 & Reticulate \\
T. monspeliaca & 1.12 & - & Granulate \\
\hline
\end{tabular}
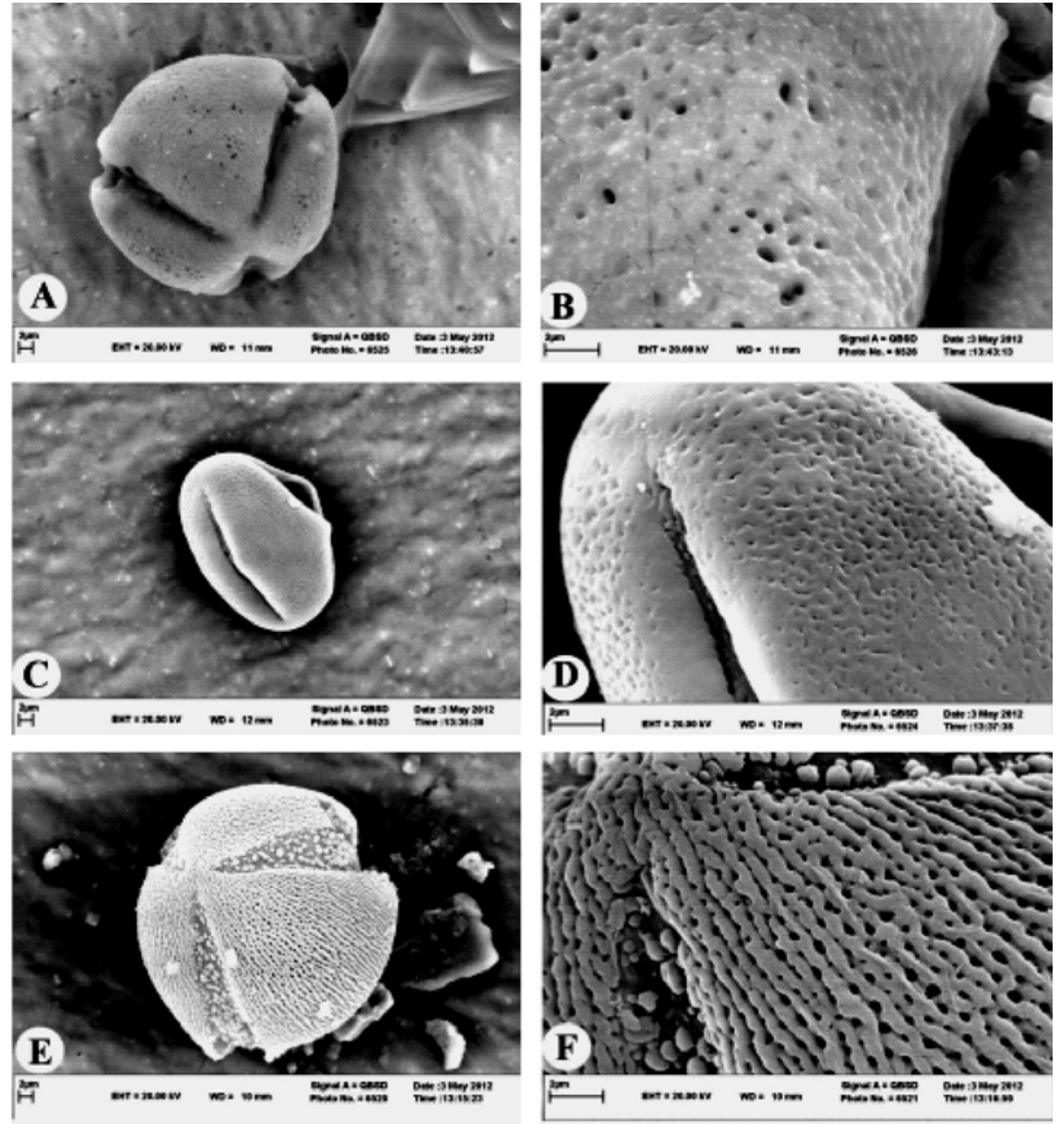

Fig. 3. The electro-micrograph of pollen ornamentation. (A,B) echinate-porate in $T$. orthoceras $\times 5000$, 20000. (C,D) perforate in T. monantha subsp. monantha $\times 5000,20000$. (D,E) reticulate in T. foenumgraecum $\times 5000,20000$. 
Based on above results, morphological characters and pollen ornamentation helped to identify species and their circumscription.

\section{References}

Chase MW and Reveal WJ 2009. A phylogenetic classification of the land plants to accompany APG III.. Botanical J. Linn Soc. 161: 122-127.

Davis PH 1989. Flora of Turkey. Vol. 10 Edinburgh University Press publishers. pp. 843.

Erdtman G 1966. Pollen morphology and plant taxonomy. Hafner Pub.Co, New York. pp. 191.

Fedorov A 1987. Flora of Russia. Vol. 1. A.A. Balkema publishers. pp. 568.

Gazar, M 2003. Pollen morphology of the three genera of subfamily Papilionoideae in Egypt (Melilotus, Trifolium, Trigonella). Acta. Bot. Hung. 45(3-4): 279-286.

Lashin Gamal MA 2006. Comparative morphology of pollen grains of some taxa of Trifolieae (Fabaceae: Papilionoideae) from Egypt. Intl. J. Bot. 2(3): 270-277.

Mabberly DJ 1977. The plant-book, $2^{\text {nd }}$ ed. A portable dictionary of the vascular plants. Cambridge University press publishers. pp. 858.

Moore P, Webb J and Collinson M 1991. Pollen analysis ( $2^{\text {nd }}$ ed). Blackwell Science publisher, Oxford. pp. 216.

Mousavi TS and Khosravi AR 2010. Patterns of distribution in the family Fabaceae (except Astragalus) in Iran. Iranian. J. Bot. 16: 303-313.

Punt W, Hoen PP, Blackmore S, Nilsson S and Le Thomas A 2007. Glossary of Pollen and Spore terminology, Review of Palaeobotany and Palynology 143(1-2): 1-81.

Ranjbar M, Karamian R and Hajmoradi Z 2012. A new species and taxonomic studies in Trigonella sect. Ellipticae (Fabaceae) in Iran. Ann. Bot. Fenn. 49: 279- 287.

Rechinger KH 1984. Flora Iranica. Vol. 157. Akademische Druck-u. Verlagsanatalt. Graz. Austria. pp. 503

Taia W 2004. Palynological study within in tribe Trifolieae (Leguminosae). Pak. J. Biol. Sci. 7(7): 13031315. 